\title{
17-Modern Türk şiirinde sahihlik sorunu: Filoloji ve poetika
}

\section{Servet GÜNDOĞDU1}

\begin{abstract}
APA: Gündoğdu, S. (2020). Modern Türk şiirinde sahihlik sorunu: Filoloji ve poetika. RumeliDE
\end{abstract} Dil ve Edebiyat Araştırmaları Dergisi, (Ö8), 224-233. DOI: 10.2900o/rumelide.824552.

\section{$\ddot{\mathbf{O z}}$}

Modern Türk şiirini "sahihlik” (otantiklik) kavramı bağlamında tanımlama çabası Yahya Kemal'den çağdaş Türk şiirine uzanan bir açıklıkta, ilk bakışta 'geleneğe sadakat' ilkesini benimser görünmektedir. Bu yaklaşım tarzında bir şiir ancak böylesi bir sahihlik kriterine uyduğu sürece şiir olarak kabul edilebilir. Bu bağlamda sahihliğin şiir için normatif ve kelimenin Grekçe kökeni de düşünüldüğünde otoriter bir kriter olması ile filolojinin köklü kavramlarından biri olması arasında ne tür bir ilişkinin olabileceği Türk eleştiri geleneğinde henüz soruşturulmamıştır. Klasik filolojinin sahihlik dediği husus antik klasikler bağlamında bir metinsel mükemmeliyet (tamlık) tasarımına sahip olmalarından ileri gelmektedir. Metinsel mükemmeliyet fikrine karşılık modern şïrin en temel vasıflarından birisi sembol kavramı etrafında parçalılık veya tamamlanmamışlıkla var olmasıdır. Bu noktada sahihliğin modern şiiri tanımlama ve aynı zamanda geleneğe sadakat imkânı ne ölçüde geçerliliğini sürdürebilmektedir? Bu yazıda bu sorun etrafında sahihliğin "sadakat" şeklindeki filolojik kullanımının ötesinde Heidegger'in sahihlik ontolojisi bağlamında, okurun tecrübe ettiği şiiri geleceğe yönelik öngörülemez şekilde kendi dünyasına tatbik etme hadisesinde açı̆̆a vurduğu ileri sürülecektir. Modern Türk şiirinin kurucu isimlerinden Yahya Kemal şiir üzerine yazı ve sohbetlerinde arketip sorununu; teori ve pratik arasındaki uyum sorununu; ses ve anlam ilişkisi ve tamirat olarak sahihlik konularını kanaatimizce bu perspektiften ele almış görünmektedir. $\mathrm{O}$, geçmişin metinlerini güvenilmez kılan siyasi filolojiden ziyade, bir metnin edebiliğinin ne tür bir okuma tecrübesini beraberinde getirebileceğiyle ilgilidir.

Anahtar kelimeler: Modern Türk şiiri, sahih şiir, Yahya Kemal, filoloji, poetika

\section{The authenticity problem in modern Turkish poetry: philology and poetics}

\begin{abstract}
The attempt to define poetry with the concept of "authenticity" has been a common trend among the better of the critics of the Turkish poetry since the period of Yahya Kemal. According to this approach, a poem is a "real" poem when it is authentic. In other words, such critics have assumed that authenticity is a norm for poetry. On the other hand, although the concept of authenticity it has a long history with some ancient Greek origins and used by certain philologists over the years, the place of this concept in the Turkish poetry has not yet been investigated in detail. For example, ancient Greeks thought that some texts were authentic because they were complete and perfect in terms of structure. However, it is known that contrary to this idea, modern poetry is fragmentary and incomplete. At this point, righteously we may ask ourselves this fundamental question: To what extent does authenticity still have the possibility of defining modern poetry and at the same time loyalty to tradition? In this article, we will discuss this problem by focusing on the philological
\end{abstract}

Dr. Öğr. Üyesi, Samsun Üniversitesi, İktisadi, İdari ve Sosyal Bilimler Fakültesi, Türk Dili ve Edebiyatı Bölümü (Samsun, Türkiye) servet.gundogdu@samsun.edu.tr, ORCID ID: oooo-0001-8370-2726 [Makale kayıt tarihi: 11.09.2020-kabul tarihi: 20.11.2020; DOI: 10.29000/rumelide.824552.]

Adres

Osmanağa Mahallesi, Mürver Çiçeği Sokak, No: 14/8

Kadıköy / Istanbul / TÜRKIYE

e-posta: editor@rumelide.com

+90 (505) $7958124 /+90$ (216) 7730616
Address

Osmanağa District, Mürver Çiçeği Street, No: 14/8

Kadıköy / Istanbul / TURKEY

e-mail: editor@rumelide.com

+90 (505) 7958124 / +90 (216) 7730616 
usage of authenticity as "loyalty". In this regard, Heidegger's understanding of authenticity will help us because in Heidegger's ontology of authenticity, manifests itself in the case of the reader applying the poem he experiences to his world in an unpredictable way for the future. This study believes that Yahya Kemal, one of the founding figures in modern Turkish poetry, in his writings and conversations on poetry, discusses the archetype problem; the problem of compatibility between theory and practice; the relationship between sound and meaning; and authenticity as emendation. Because, unlike the classical understanding of authenticity, Yahya Kemal was concerned about what kind of reading experience a text can bring with itself.

Keywords: Modern Turkish poetry, authentic poetry, Yahya Kemal, philology, poetics

\section{Giriş}

Modern Türk şiirini "sahihlik" (otantiklik, authenticity)2 kavramı bağlamında tanımlama çabası Yahya Kemal'den çağdaş Türk şiirine uzanan bir açıklıkta, ilk bakışta 'geleneğe sadakat' ilkesini benimser görünmektedir. 3 Geleneğe sadakat, klasik filolojinin "eski metinleri unutulmaktan kurtarma" (Bayrav: 1998, 12) veya ihyâ ilkesiyle ilişkili görünmektedir. Burada eski metinlere sadakat öncelikli sorumluluk olarak belirlendiğinde en büyük sorun modern ufuk içerisinde metin anlayışının değişimi olarak karşılarına çıkar. Dolayısıyla filolojinin bu noktada asli amacı bugünkü ufuk veya birikim içerisinde anlaşılmasında güçlük duyulan eski metinleri okunabilir ve anlaşılabilir kılmaktan ibarettir. Bu sorun etrafında eski metinlerin sözlü ve ritüalistik icraya dayalı gelenekten ritüel bağı kaybolmuş yazılı geleneğe geçişte muhtelif varyant veya rivayetlerinin toplanması, hangi varyantın arketip (ilk model) olarak belirleneceği, metnin grameri (üslubu), dönemi, yazarı veya okur çeşitliliğinin metin algısını üretmede ne tür rolleri olabileceği gibi başkaca cevaplanması güçlük çıkaran sorunları beraberinde getirir. 4

Bilhassa onsekizinci asrın sonunda ancients-moderns ayrımından hareket eden filolojik bilinç, modern Türk şiirinde, başta Yahya Kemal'de olmak üzere klasik şiirle anlamlı bir bağ kurma çabasındaki modern şairlerin poetik metinlerinde kendisini gösterir. Modern şiiri eski şiirin yenideninşası veya taklidi yoluyla gerçekleştirme çabası, başlangıçta inşa edilmiş olanı tamamlanmış ve geride bırakılmış olarak mı görür? Bu bağlamda geleneksel metinler, klasik metinlerin tamamlanmışlığı veya mükemmelliği nosyonu üzerinden sadece tashih edilebilen ama asla anlam üretimine dahil edilmeyen bir çalışma konusu mudur? Bununla beraber tashihe ihtiyacı olmayan, sadece taklit edilebilen klasik şiir ise asla bugüne ulaşamayan, Hegel’in tabiriyle geçmişte kalmış bir şeyse, geçmişte kalanın taklit edilebilmesi mümkün müdür? Yoksa modern bilinçle gerçekleştirilen taklit faaliyeti yeni bir şiir üretme arayışından çok, eski metni iyileştirme veya modernize etme amacını mı benimsemektedir? Klasik filolojinin tashih anlayışı ile neoklasikçi taklit faaliyeti kanaatimizce hem eski metinleri geçmişe

$2 \quad$ Köprülü authenticity kelimesini Türkçeye vusûk diye çevirir (Köprülü, 1999: 32). Bu kelime güçlü bir bağ ve bozulmaz bir antlaşma anlamına gelir. Tanpınar'ın Tanzimat'ta tiyatro üzerine verdiği derslerin notlarında otantiklik kelimesinin kullanıldığı yerde parantez içerisinde ayniyyet kelimesi verilir (Tanpınar, 2004: 137). Özdeşlik veya tam bir mutabakat anlamına gelen bu kelimenin hangi bağlamda kullanıldı̆̆ı belirsizdir. Zeynep Sayın "Sahicilik İlkesi ve Cokkültürcülük" yazısında ise kavramı sahicilik olarak tercih eder (Sayın, 1996: 282-288). Gerçeklik, otantiklik, özgünlük, özdenlik, (kendine-)hasslık, hâlis(kendi-)lik şeklinde de kullanılan bu kavramı bu yazıda genel anlamda, filolojik bağlamını ve aynı zamanda Türk-İslam kültüründeki çok yönlü anlam alanı dikkate alınarak sahihlik olarak tercih edilmiştir.

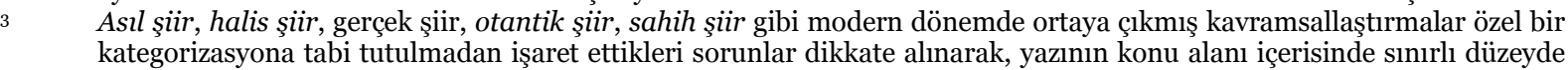
tartışılmıştır.

$4 \quad$ Jean Pierre Vernant bilhassa mitolojinin filolojik analizinde temel ilginin şu amaç ve sorular etrafinda oluştuğunu belirtir: "[B]ir söylenin tam sicilini, kökenini, ömrünü belirlemektir: Nereden gelmektedir, nerede ortaya çıkmıştır, ne zaman oluşmuş̧tur, sırasıyla hangi biçimlere bürünmüştür, rastlanan ilk değişkesiyle ilgili ne biliyoruz, ana örnek olarak neyi alabiliriz?" (Vernant, 1996: 220).

Adres

Osmanağa Mahallesi, Mürver Çiçeği Sokak, No: 14/8 Kadıköy / Istanbul / TÜRKIYE e-posta: editor@rumelide.com +90 (505) $7958124 /$ +90 (216) 773 o 616
Address

Osmanağa Mahallesi, Mürver Çiçeği Sokak, No: 14/8

Kadıköy / Istanbul / TURKEY

e-mail: editor@rumelide.com

+90 (505) 7958124 / +90 (216) 7730616 
ait konumlandırmaları hem de bu metinlerin anlam üretimleri noktasında yeterli düzeyde olmadığına yönelik bir imayı taşımaları nedeniyle aynı ölçüde sorunludur. Metinleri tashih etme ve neoklasikçi taklit çabası büyük ölçüde sahihliğin doğasında bulunan bir belirsizliği göz ardı eder. Sahihlikteki bu belirsizlik okurun tecrübe ettiği şiiri geleceğe yönelik öngörülemez şekilde kendi dünyasına tatbik etme hadisesinde kendisini gösterir.

Yukarıda ifade edilen soruları ve sahihliğin doğasındaki belirsizliği daha iyi anlayabilmek için önce sahihlik kavramı etrafında filolojinin tarihsel sürecini kısaca ele almak gerekli görünmektedir. Devamında ise Yahya Kemal'in filoloji temelli sahihlik poetikasının onun asıl şïr veya halis şïr dediği kavramsallaştırma etrafında kendisini hangi konu ve tartışmalar içinde gösterdiği belirlenecektir. Son olaraksa sahihlik veya asıllık kavramının poetika bağlamında kullanımının okurun sonlu bir varlık olarak zamansallığı konusundan bağımsız şekilde anlaşılamayacağı ileri sürülerek sahihliğin okur ve şiir arasında bir anlama sürecinde kişinin kendisini dilsel bir durumda anlama ve bu dilsellik serüvenine kendisini uygulaması olarak anlaşılması gerektiği üzerinde durulacaktır.

\section{Sahihlik kavramı etrafında filolojinin tarihsel süreci}

İlginç bir şekilde antik çağın üstünlüğünü zayıflatmaya başlayan, onsekizinci asrın sonunda gelişen filoloji ve arkeolojinin yardımıyla doğal ve tarihi yeni bilimler olur. Filoloji bir yandan kelimelere başlangıçtaki anlamını verme, öte yandan metinleri onararak mükemmel hale getirme çabasıyla metinler-arası bir hiyerarşi kurarak tekillik alanı inşa eder.

Her ne kadar Rönesansın hümanist ruhu ile birlikte eski Yunan ve Roma dönemlerine ait eserlerin üzerinde çalışma isteği uyansa, aynı zamanda üniversite ve akademilerde çalışan hümanist düşünürler klâsik metinlerin otantikliğini tespit etmek ve orijinal metne en yakın metinler üretebilmek için ars critica adını verdikleri filolojik eleştiri sanatını geliştirmiş olsalar da bu otantiklik arayışı siyasi düzlemine onsekizinci asrın sonunda ulaşır. ${ }^{5}$ Sistematik, bütüncül ve objektivist yorum teorilerinin ortaya çlkışı böylesi bir filolojik arka plana sahiptir (Tatar, 2004: 16). Çünkü bilhassa ondokuzuncu asırda filoloji, bütünlük tasarımından hareketle eski metinlerin nesnel bir sahihliğini tespit etmeye çabaladığında -buna İncil de dahil olmak üzere- antik dönemin en bilinen metinleri bile tutarlılık ve bütünlük noktasında istikrarsızlaşmaya başlar.

Onsekizinci asırda geçmişi ve geçmişin metinlerini normatif bir tarzda konumlandırma girişimi filolojinin tarihsel arka planıyla büyük ölçüde farklılık arz eder. "Roma imparatorluk dönemine kadar antik filolojinin başlıca işi gramer sorunlarını ele almak ve hypomnemata, yani şerh yazmaktı" (Blanck, 2000: 159). Bilhassa bir disiplin olarak grammatica metinsel otantiklik ve linguistik doğruluk konusunu emendatio (tashih, onarım) kapsamında ele almıştır (Irvine and Thomson, 2005: 15-16). Filoloji bu gramatik amacından uzaklaşıp metinlerin otantikliğini bir ölçüde normatif biçimde belirlemeye başladığında geçmiş algısını da dönüştürmeye başlar. Charles Taylor, Modernliğin Sıkıntıları isimli çalışmasında otantikliğin kaynă̆ını onsekizinci asrın sonunda, romantizmde bulur (Taylor, 2011: 28). Dolayısıyla filoloji metnin grameri ve anlamından ziyade metnin otantikliği vurgusunu öne çıkardığında geçmiş hakkında kuşkulu bir ilişki başlamış olur.

Bayrav, filolojik eleştirinin "arı metin" algısından söz ederken bu arı metni oluşturma tarzlarını şöyle açıklar: "İster kutsal ister laik olsun; metinlerin bilimsel olarak incelenmesi, kısaca, filolojik elestiri, Hümanistlerle baslar. (...) Filolojik eleștiri, kutsal kitaplardan düzmece parçaları, tarih kitaplarında gerçek olaylara karıșan menkıbeleri, hukuk kitaplarında temel metne eklenen șerhleri ayırmak amaciyle girișilen çalışmalarla bașlar.” (Bayrav, 1998: 60-61). 
Metnin otantikliği bir biçimde kabul edilmediğinde metin normatif veya kanonik güç kazanamadığından otantiklik bir metnin daha en başından nasıl yorumlanacağını da belirlemektedir. Dolayısıyla bu bağlamda bir metnin otantik olup olmamasıyla ilgilenmenin dini, hukuki, tarihsel, siyasi ve ideolojik bir bağlamı vardır. Otantikliğin tartışma konusu olduğu her durumda dolaylı soru geçmişle bağın ahlaki ve siyasi düzlemde ne şekilde kurulabileceği sorusunda düğümlenir. ${ }^{6}$

Geçmişe kuşkulu bakış sürerken öte yandan, Romantikler ve halefleri, antik klasikleri taklit fikrine eleştiriler getirmeye başlar. Ondokuzuncu asrın sonundaki modernist hareket, kadimlerin uzun süren ve kısıtlayıcı otoritesine karşı bir direnç olarak görülebilir. Bu noktada romantiklerin "edebilik" nosyonunu geliştirerek edebi dil ve gündelik dil, bununla beraber edebi dilin diğer söylem tarzlarından farkını vurgulaması bu normatif filolojinin her türden metni aynı kategoride ele alma yaklaşımını da dolaylı olarak sorunsallaştırır.7

Yeni ve daha radikal modernler eskinin yerini alırken, antik çağın savunması, eski ve antik dünyalar hakkında daha derin bir bilginin etkisi altında geriler. Böylece antik metinler çağdaş düşünce için farklı bir açıdan yabancılaşmaya ve uzaklaşmaya başlar. Klasikler, uzun süre hüküm sürdükleri okullarda ve kamusal yaşamda büyük ölçüde terk edilir. Antikler ve modernler arasındaki uzun çekişme modernler lehine hemen hemen sona erer.

Bu noktada filolojinin ön varsayımlarının poetika bağlamında test ve revize edilmesi ve bu bağlamda filolojiye ilişkin yeni soruların sorulması gerekli görünmektedir. Bu sorular eski metinlerin değil, yirminci asrın başında ilgisiz bırakılmış filolojinin bizatihi kendisinin poetik düşünce ortamında varlık kazanmasına imkân verebilecektir. ${ }^{8}$

\section{Yahya Kemal'in otantiklik poetikası}

Bu bağlamda modern Türk şiirinde Yahya Kemal özel bir fenomen teşkil eder. Onun asıl şïr dediği şey kavramsal düzeyde filolojik bir arka plana sahiptir. Fakat bu düşünce bilhassa antik filolojinin anlam arayışı ile onsekizinci asrın bütünlük siyaseti arasında konumlandırılmayı beklemektedir. Çünkü Yahya Kemal arketip sorununu; teori ve pratik arasındaki uyum sorununu; ses ve anlam ilişkisi ve tamirat olarak sahihlik konularını çok farklı açılardan ele alırken geçmişin metinlerini güvenilmez kılan siyasi filolojiden ziyade, edebi metnin edebilik vasfının ne tür bir okuma tecrübesini beraberinde getirebileceğiyle ilgilidir. Bu ilgi, okurun eski ve yeni metinler arasında kendi şimdisini geleceğine nasıl projekte edebileceği gibi bir soru etrafında ontolojik bir arayış içerisinde görünmektedir. Çünkü geçmiş, kişinin şimdisini geleceğine nasıl projekte ettiği sorusu sorulmadan anlaşılabilir hale gelemeyecektir. Dolayısıyla bu tarzda bir sahihlik yaklaşımı, okuru, geçmişe ihanet veya sadakat diyalektiğinin ötesine taşır.

Jan Ziolkowski, filoloji teriminin daha ifade edildiğinde bile kutuplaştırıcı bir etkisi olduğunu fark ettiğinde "Neden böylesine takdire şayan bir teknik ve bilgi dizisi, bir tarafta böylesine şiddetli bir gurur ve koruyuculuk, diğer tarafta bu kadar derin bir güvensizlik ve hatta hınç uyandırsın?” diye sorar. (Ziolkowski, 1990: 2)

$7 \quad$ Ondokuzuncu asrın "Alman filoloğu A. Böckh, filolojinin yalnızca edebi metinlerin (belle lettre) değil, türü ne olursa olsun tüm metinlerin (lettre) bilimi olması gerektiğini iddia etmiş ve dev eseri Filolojik Bilimler Ansiklopedisi’ni bu doğrultuda yazmıștır" (Dilthey, 1999: 135).

$8 \quad$ Filolojiye dönüs Paul de Man'ın yirminci asrın son ceyreğinde gerçeklestirdiği özel bir çabadır. De Man'ın makalesi Harvard'ın İngilizce profesörlerinden Walter Jackson Bate tarafından yazılan 1982 tarihli "The Crisis in English Studies" isimli makaleye cevaptır. Bate bu yazısında Rönesans'tan bu yana yüksek öğretimde hüküm süren hümanist entelektüel ideali filolojiyle özdeșleștirerek sonunun geldiğine ișaret eder. Çünkü yeni akademik eleștiri, yaşamın bir yorumu ve eleştirisi olarak geleneksel hümanist edebiyat anlayışını terk etmiş ve ortak tecrübelere kendisini kapamıştır (de Man, 2002: 21-26).

Osmanağa Mahallesi, Mürver Çiçeği Sokak, No: 14/8

Kadıköy / Istanbul / TURKEY

e-mail: editor@rumelide.com

+90 (505) 7958124 / +90 (216) 7730616 
Albert Sorel'in siyasi ve edebi tarihi kaynaştıran tarih felsefesinden etkilendiğini sık sık dile getiren Yahya Kemal bu etkiyle kendi milletine ilişkin tarihsel okumalara başladığında yeni bir ufuk fark eder. $\mathrm{Bu}$ beliren ufuk onun "mesafenin güçlüğü" olarak dile getirdiği yeni ve başka bir şiir, dil ve tarih sorunuyla yüzleşmesini sağlar. "Lâkin yeni bir çı̆̆ırı sezmekle ona vücûd vermek arasında çok aşılamaz bir mesâfe vardır" (Yahya Kemal, 2005: 258). Eski şiirlerle kurulan bağda neoklasikçi taklidin sınırlarını aşabilmenin güçlüğü ile yeni çeşitte bir mısra söylemenin imkansızlı̆̆ı onun aynı anda tecrübe ettiği bir açmazdır (aporia).

Yahya Kemal bu açmazı şiiri mazmuna dayalı bir tekrar anlayışına indirgeyen eski şiirle, şiiri yazılan ve okunan bir şey olarak nesre yaklaştıran yeni şiir arasındaki sorunları gidermeye çalışarak aşmayı dener. Halis şïr diye adlandırdığı bu şiir, nesirden farklı ama tekrardan da uzak olmalıdır. Nesir ve şiir arasında oluşturmaya çalıştı̆̆ fark ona dille kuracağı yoğun ilişki nedeniyle geç ve güç söyleme, bir mısra üzerinde haftalarca durma gibi bir zorunluluğu beraberinde getirir.

Yahya Kemal'in başka şairlerin şiirlerini düzeltme girişimleri filolojik tamirat bağlamında değerlendirilebilir.9 Yüksek düzeyde filolojik bir bilince sahip olan Yahya Kemal'in ${ }^{10}$ şiirlerinin metinsel mükemmeliyet bağlamında ele alındığı sıklıkla görülür (Doğan, 2011: 101-113). Ona yönelik estet tanımlaması, bir mısrayı bile uzun yıllar içerisinde yazma çabası hep bu filolojik yaklaşım etrafındadır. Buna karşılık o, kelimeleri özenle seçerken dekoratif bir estetikçilikten uzaktır. Çünkü onun şiirlerinin yorumsal boşlukları farklı bir bütünlük algısını da açığa çıkarır. Burada mükemmel olan yorum için açıllık ve mesafe üreten anlamına gelir. Dolayısıyla mesafenin güçlüğü sadece şairin şiiri yazma süreci değil, daha ziyade okurun şiirlerle kurduğu ilişkide açığa çıkmaktadır. ${ }^{11}$ Bu bakımdan bakımdan Yahya Kemal okurun şiir tecrübesine yönelik de daima bir varsayıma sahip olmuştur.

Yahya Kemal onbeş senede tamamladığı "Açık Deniz" isimli otobiyografik şiirindeki "Hâlâ dilimdedir tuzu engin denizlerin" (Yahya Kemal, 1974, 15) misraiyla sonsuzluk ve fanilik arasında kalan insanın anlam arayışının bir ifadesini bulur. Mahzun hudutların ötesine, ufuktaki sonsuzluğun tadına eriştiği yerde "vezin ve kafiye ile ifade edilen, hakikatte nesir olan şiirimizden başka bir şiir" görür. Sahihlik olgusunu burada Yahya Kemal mısrâ gûyâ hissin ta kendisi imiş gibi kaarie samîmî bir vehim vermek olarak özetler. Fransız sembolist şair Stéphane Mallarmé’nin "kapalı, müphem, akîm, daha fazla musikiye sapıtmış, hasılı her ne olursa olsun meziyyet veyahut nakisa telakki olunan bütün evsafıyla beraber" (Yahya Kemal, 2005, 15) şair olduğunu söylemesi önemlidir. Çünkü noksanlık ve meziyyet şiirin varolabilmesi açısından aynı ölçüde önem arz eder.

9 "Unutulmaktan kurtarılan şarkılar hayal edelim; bunların yazıya geçirildiğini, yeni baştan söylendiğini ve gençlere öğretildiğini hayal edelim. Ve çağlar boyunca, farklı kopyalar (çeşitli "gelenekler") ortaya çıtıkça, eklemeler yapılmış, birbiriyle uyuşmaz örnekler ortaya çıkmış, sözcükler eskimiş, dil kullanımları değişime uğramış, yer adları değişmiş̧ olsun. Yine varsayalım ki, en iyi metni kurtarma kaygısıyla, kütüphaneler oluşturulmuş, dilbilgisi uzmanları ișe koyulmuş olsun. Ortaya çıkan yeni eleştirel davranış, filolojik anlamıyla, onarma (restitution) eylemidir. "Onarmak", “onarma” sözcükleri eskiden günlük dilde kullanılırdı ve Dictionnaire de L'Academie 1740’ta, bu sözcükler için şu tanımları veriyordu: "Edebiyatçlar, bozulmus bir bölümü eski haline getirmek üzere düzeltmek, onu olması gereken duruma getirmek anlamında, Bir metni, herhangi bir yazardan bir bölümü onarmak, derler [...] Bu onarma yararlıdır. Bu durumda düzeltme (rétablissement) anlamına gelir"” (Starobinski, 2010: 17-18).

$10 \quad$ Yahya Kemal'in yüksek düzeyde açığa çıkan filolojik bilinci "Lisâna Dâir Güft ü Gû" isimli yazısında, bilhassa Nedim divanına ilişkin yaptığı, bütün divanda sadece tek bir yerde -yor ekinin bulunduğuna ilişkin şu özgün tespitte kendisini gösterir: "Lisan denildiği vakit yazı lisânını anlıyorum. Yoksa bilirim ki Nedîm sokakta ve evde bizim gibi konuşurdu; konuşurken sîga-i hâl'leri bizim gibi geliyor, söylüyor, geçiyor tarzında tekellüm ederdi, fakat yazarken bu yor'ları hazfeder, dört asır evvelki cedlerimiz gibi muzâri' şeklinde yazardı. Nedîm'in bütün dîvânında, zannedersem bir tek yor'a tesâdüf edilir" (Yahya Kemal, 2005: 99).

Walter Benjamin'in sanat eserinin aurası dediği şey de bir anlamda edebi eserin oluştuğu anda orada kendisiyle karşılaşacak olanlar için durmaya başlamasıdır (Benjamin, 2007: 50-86). 
Bir yandan Fransız sembolist şiirine ilgisi öte yandan bunun da ötesine geçerek Yunan ve Latin klasiklerine kadar uzanma arzusu onun şiiri öz şïr, rythme, derûnî ahenk gibi kavramlarla düşünmesine neden olur. "Halis şiir” olarak ifade ettiği, nesir ve bu anlamda müddeadan özerkleşmiş, deruni ahengi olan, manadan ziyade lafza, meselden ziyade bercesteye dayalı şiirdir. Yine de Turan Koç’un "Varlıkla Buluşan Dil” isimli yazısında işaret ettiği gibi "Başarılı ve sahih bir şiir, belirli, sabit ve değişmez bir kesinlik, tam olarak ifadeye kavuşmuş bir bütündür. O yüzden, şiirde ifade edilenle ifade tarzını birbirinden ayırmak mümkün değildir” (Koç, 2014: 73). Bu doğrultuda Yahya Kemal sahih şiir arayışında bir yandan anlam ve ses, diğer deyişle ifade edilenle ifade tarzı dengesini muhafaza etmeye çalışırken öte yandan dilin ritmik sesini bir filolog titizliğiyle rafine şekilde duyurmaya çalışır.

Her ne kadar asıl veya halis şiir diyerek başkaca şiirleri ikincil bir düzlemde gördüğü gibi bir yorum ilk bakışta doğru gibi görünse de Yahya Kemal kendi görüşünü yegâne doğru saymaktan açıkça uzaktır (Yahya Kemal, 2005: 46). Birbirine tamamen zıt şiir çı̆̆ırları hakikatin başkaca yönlerine sahiptir. Bu bakımdan sanatın sanat için olduğu veya sanatın toplumsal olduğu yolundaki karşıt yaklaşımların her birinin güçlü edebi üretimleri kendisini kabul ettirmiştir. Böylece şiir bağlamında sahihlik ve gayrisahihlik tam anlamıyla ayrıştırılamayacağı gibi bu kategorik fark birinin diğerinden daha düşük bir dereceye sahip olduğu anlamına da gelmez. Gayri-sahih şiir hala dile, dünyaya ve geleceğe dönük bir ilgiyi, merakı ve anlaşılır kılınmaya çalışılan bir belirsizliği işaret eder. Burada asli fark, sahih şiir tecrübesinde kişinin kendisi ile dünya arasında bir açıklığı ve fani bir varlık oluşunu idrak etmiş olmasıyla oluşur. ${ }^{12}$

Yahya Kemal'in sık sık referansta bulunduğu Mallarmé, şiirin sahihlikle bağına modern dönemde dikkat çekenlerden birisidir. Mallarmé için kelimeler göstergelerden daha fazlasına sahiptir. Çağrışımsal ve ritüalistik olarak kullanıldığında kelimeler ideal bir dünyaya girmemizi sağlayan araçlardır. "Şiir," Mallarmé'nin 1886'da tanımladığı gibi, "varoluş durumlarının gizemli anlamının, temel ritmine geri getirilmiş insan dili aracılı̆̆ıyla ifadesidir: Dünyada geçici ikametimize sahihlik bahşeder ve yegâne ruhsal ödevi oluşturur" (Michon: 2016). Dünyanın geçici ikametgâh olarak şiirin belirsiz dilinden görünür kılınması bu bakımdan sahihlik tasarımında ortak bir poetik tutumdur. Buna karşılık klasik filolojinin sınırlılık veya parçalılık yerine öne çıkardığı bütünlük tasarımı şiirin belirsiz ve sembolik anlam dünyasını çok büyük ölçüde göz ardı eder. Yahya Kemal, İlyada'nın tek bir şair olarak Homeros tarafından değil de asırlar boyu farklı şairlerin söyledikleri parçalardan hareketle toplandığı yönündeki filolojik görüşe karşılık Schiller'in eserin tek bir şairin eseri olduğu yönünde yaklaşımını Nef'̂̀’nin "Ehl-i dil birbirini bilmemek insâf değil” mısraından hareketle şairlerin şiirin mahiyetini, şair olmayan (filolog) alimlerden daha iyi görebileceği yargısına getirir (Yahya Kemal: 2005, 23).

Klasik filolojinin ele aldığı sahihlik sorunu çok büyük ölçüde bu tartışma etrafında şekillenir. "Nedîm'in Evi” isimli yazısında Nedim'in o dönem ellerde gezen iki matbu divanıyla beraber elyazması divanlarının da olduğunu belirtir. Bu divanlar arasında farklılıklar olduğunu ve yeni birçok gazelinin Ali Emîrî tarafından o günlerde el yazması divanlardan ortaya çıkarıldığını bu yazıdan öğreniriz. “Acaba bu mısralar muhakkak onun mudur?" tarzındaki filolojik soruya "bu ihtiyat beyhudedir" diye karşılık verir. Nedîm'in "Ma'lûmdur benim suhanım mahlâs istemez/ Fark eyler ânı şehrimizin nüktedanları" beytini anarak his yoluyla bu mısraların onun olduğunun belirlenebileceğini ifade eder (Yahya Kemal, 2005: 66-68). Bu minvalde Nermi Uygur "asıl şiir"in hangi metin veya kimin yazdığı metin olduğu sorusuna yönelik arayışların sorunlu taraflarını ele aldı̆̆g "Biricik" isimli yazısında "her

12 Heidegger'in ölüme yönelik sahih varlı̆̆a ilişkin eksistensiyal tasarımı için bakınız. Martin Heidegger (2008). Varhk ve Zaman, Kaan Ökten (Çev.). İstanbul: Agora, s. 275-282. 
örnek asıldır edebiyat alanında" diyerek şu veya bu müsveddenin, el yazısının veya matbu eserin birinin diğerinden daha asıl olamayacağını belirterek "bu örneklerden hiçbirinin asıl şiire daha "sadık" olduğunu öne süremeyiz. Asıl şiir hepsinde bunların” der (Uygur, 1985: 31).

\section{Okur ve şiir arasında beliren sahihlik}

Bu noktada şiirin veya metnin sahihliği sorunundan okurun sahihliği sorununa geçildiğinde bir ötekilik olgusu olarak, Heidegger'in kaygısına kulak verilirse, şiire yönelen kimse kendi otantikliğini riske mi atmış olur? Tatar'a göre "sanat eserleri sayesinde bizler varlığın hakikatine yani otantik ifşasına tanık oluruz" (Tatar, 2014: 55). Tam da bu risk durumu, şiirin mutlak bir öteki olarak okuyanın diline direnç göstermesi ve okuyanın da bu direnç karşısındaki anlama çabası, okuyan ve şiir arasında otantik bir ilişkiyi açığa çıkarır. Dolayısıyla sahihlik salt şiire veya okura hasredilebilecek bir şey olmaktan öte bu ilişkisellik içerisinde açığa çıkar ve belirli bir öz olarak konumlandırılmaksızın dönüşmeyi sürdürür. Dolayısıyla şu durumda bir okurun, potansiyel otantiklik için çaba harcamadığı, aynı zamanda otantikliği tecrübe edemediği durumda sahih olmadığı söylenebilir. Kendi dilsel sınırları, başkalarıyla daima uyum içerisinde kaldığında bir anlam üretemeden kapanır. David Couzen Hoy'un da dikkat çektiği üzere “Heidegger'de sahihlik kavramı, Angst'in fenomenolojik bir analizinden kaynaklanır, ancak açıçca kişinin hayatını nasıl yaşayacağına dair normatif çıkarımlara sahiptir. Sahihlik, yalnızca ölümün kaçınılmazlığının fenomenolojik olarak kabulü değildir; aynı zamanda insan sonluluğunun göz ardı edildiği veya reddedildiği bir yaşamın eleştirisini de içerir” (Hoy, 2009: 239).

Dolayısıyla sahihlik Homeros veya Yunus Emre'nin gerçek birer şahsiyet olduğunu ve şiirlerinin onların söyledikleri şekliyle, tahrif edilmeden bize ulaşması veya bir şeyin içeriğinin onun gerçekliğiyle örtüşmesi, dolayısıyla uydurulmuş olmaması gibi bir anlama gelmez. Böylesi bir sahihlik anlayışı kelimenin kökensel benzerliği de dikkate alındığında otoriterliği ve bununla ilişkili olarak normatifliği beraberinde getirir. Filolojinin tashih ilkesi bir yandan eski metni daha korunaklı kllmayı amaçlarken öte yandan bu korumacılık o metni öylece kabul etmeyi ve kendi hakikatini açığa çıkarmasını baskılar.

Otoritesini kendinden alan şey, sahih şiirin gerisinde duran bir ilke veya düşünme tarzı değildir. Sahih şiir başkalarına açıklık anlamına geldiğinde geçmişe, yani yazarına, dönemine veya belirli bir dünya görüşüne doğru bir hareketten öte, geleceğe yani olası okurlarının tarihsel ve zamansal yorum alanında kendisini biçimlendirmesine dönüktür. ${ }^{13}$ Yahya Kemal tam da bu nedenle maziyi diriltmenin imkansızlığından söz eder (Yahya Kemal, 2005: 311-312). Çünkü ona göre mazi ölmüş değildir. Saussure'ün filolojiye getirdiği yazılı dile çok bağlı kalıp yaşayan dili unutma eleştirisi bu açıdan da dikkate alınmalıdır (Saussure, 1998: 28). Çünkü o, yazılı formdaki metinleri geçmişe ait olarak gördüğünde hala benzer sorunlu bir yaklaşıma sahip olsa da, yaşayan dile işaret ettiğinde sadece dilin şimdisine değil, aynı zamanda geleceğine de işaret etmiş olur. Bu bakımdan dilin yaşayan geleceğe doğruluğu onun tam olarak tek başına kavranamayacağını ima eder.

Sahihlik bu yönüyle aynı zamanda etik bir tatbikat veya temellük (appropriation) konusudur. Fakat onun etik yönü kişinin kendisini gerçekleştirmesi ile sınırl değildir, daha doğrusu şiirde sahihlik kişinin kendini gerçekleştirme durumunu da aşan başkaca sorunları hatırlamasına uzanır. ${ }^{14}$ Bilhassa İslam hadis geleneğinde sahihlik Hz. Peygamber’in söylediklerinin doğruluğunun onaylanması

${ }_{13}$ "Edebi metnin okunmasının; okurun kendisini tarih içinde buluvermesi, tecrübenin zamansallığı, insanın ve edebi metnin tamamlanamazlığı gibi boyutlarıyla tarihsel olduğu” yaklaşımını benimseyen bir yazı için bkz.: (Gündoğdu, 2019: 351-374).

14 Taylor, "Kendini gerçekleștirme kültürü, çoğu insanın kendilerini așan meseleleri unutmasına yol aç̦”" diyerek bu soruna dikkat çeker (Taylor, 2011: 20).

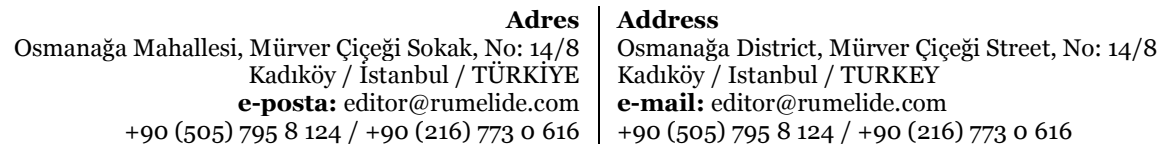


anlamında değil, söylenenle amel etme şeklinde de anlaşılır. Burada amel her ne kadar söylenenin basitçe uygulanması gibi görünse de durum çok daha karmaşıktır. Çünkü hem söylenen sözün orijinal bağlamı hem de sözle amel edecek kişinin kendi içinde bulunduğu bağlam daima farklılaşmaktadır. Bu farklılaşma durumunda tam olarak nasıl amel edileceğini bilememe, buna karşıllk daima bir arayış halinde olma hadisin sahihliği bakımından çok daha kritiktir. Sahih şiir kavramını şiir üzerine sohbetlerinde sıklıkla vurgulayan Hilmi Yavuz'un dikkat çektiği üzere "sahih şiir 'nitelikli' bir okuru ön varsayar. Sahih şiir, ancak nitelikli okur dolayımında temellük edilebilecek bir şiirdir" (Yavuz, 2012: 299). Modern Türk şiiri üzerine düşünme çabalarının, bu bakımdan sahihliğin amel veya tatbikat yönü ve doğrudan okurun metinle olan öngörülemez tecrübesi karşısında okurun niteliğini daha fazla öncelediği söylenebilir.

Sahihlik, bilhassa şiir bağlamında dili, dünyayı ve zamanları diğer insanlarla paylaşma durumudur. Gülten Akın has şïr olarak adlandırdığı şiiri, böldükçe çoğalan bir paylaşma hadisesi olarak görür (Akın, 2011: 60). Bir şiiri tek başına okumaya başlamış kimsenin sürekli ama zorunlu biçimde başkalarının dilini paylaşma durumu sahihlik ve gayri-sahihlik durumuyla ilgilidir. Lévi-Strauss etnoloğun misyonundan söz ederken ele aldığı otantiklik kavramını herkesin herkesi tanıdı̆̆ı küçük topluluklarda komşuluk ilişkisi olarak görür (Lévi-Strauss, 2012: 510). Gayri-sahihlik ilk bakışta kişinin henüz başkalarından, komşusundan ayrışmamış bir ortak dil içerisinde olduğunun farkında olmadığı bir durumu ima eder. Sahihlik ise tersine şiirin söylediğini anlamaya ve yorumlamaya çabalarken ortaya çıkan yeni sorularla yüzleşerek, dogmatik veya alışıldık varsayımların ötesinde şiirle bir ilişki kurmaya açıklık anlamına gelebilir. Ama bu noktada başka insanların şiirle kurulan ilişkide sınırlayıcı olduğu fikri bir anlamda sorunludur. Özellikle şiirin ortaya çıkardı̆̆ı temel soruları başka zamanlarda üretilmiş başka insanların yorumlarıyla birlikte anlamak, hem şiirle hem de şiir etrafında doğan diyalog ortamında sorulara bir cevap bulabilmek veya soruları daha anlaşılır kılabilmek mümkündür. ${ }^{15}$

$\mathrm{Bu}$ anlamda poetik sahihlik kişinin şiir tecrübesinde kendisini başkalarıyla konuşmaya açık tutması ve hepsinden önemlisi başkalarına kulak vermesi anlamına gelir. Bu anlamda filolojinin "yavaş okuma sanatı"16 olarak anlaşılması bir metin hakkında hızlı ve tek başına karar vermeme, ortak tecrübeyi dikkate alma ve başkalarına açıklık anlamıyla düşünülmelidir. Bu şekliyle anlaşıldığında filoloji, poetik düşünmenin gelişiminde basitçe bir safha değil, hala bir şiiri anlama olgusunun temelinde yatan bir okuma tarzıdır.

\section{Sonuç}

Sonuç olarak sahih şiir, "geleneğe sadakat" şeklindeki onsekizinci asır sonrası filolojik kullanımının ötesinde Heidegger'in sahihlik ontolojisi bağlamında metnin söylediklerinin henüz düşünülmemişliğinin tamamlığa direnci ile metnin bütünlüğü arasında konumlanan bir poetika tasarımında kendisini anlamlı bir zemine taşıyabilecektir. Böylesi bir poetika, sahihliğin ancak okurun tecrübe ettiği şiiri geleceğe yönelik öngörülemez şekilde kendi dünyasına tatbik etme hadisesinde açığa vurduğunu düşünmektedir. Modern Türk şiirinin kurucu isimlerinden Yahya Kemal şiir üzerine yazlları ve sohbetlerinde arketip sorununu; teori ve pratik arasındaki uyum sorununu; ses ve anlam

\footnotetext{
15 Abdullah Başaran, sahici edebiyatın ne olduğu sorusuna cevap ararken istifham kavramına özel bir önem atfetmektedir: "Varlığın bir yorumcusu olarak edebî metin, aynı zaman dilimini paylaştı̆̆ı okura Varlı̆ga dair sahici sorular yöneltebildiği ölçüde sahici bir metin olarak adlandırılabilecektir; ki böylelikle okur da rastladığı bu soruları kendisine sahiden sorabilsin ve başkalarının cevaplarını tekrar etmekten ziyade metnin sorusuna göre kendi cevabını, kendi konumunu belirleyebilsin" (Başaran, 2017: 237).

16 Roman Jakobson filolojiyi “yavaş okuma sanatı” olarak tanımlar (Ziolkowski, 1990: 12).
} 
ilişkisi ve tamirat olarak sahihlik konularını kanaatimizce bu perspektiften ele almış görünmektedir. $\mathrm{O}$, geçmişin metinlerini güvenilmez kılan siyasi filolojiden ziyade, edebi metnin edebilik vasfının sahih bir okuma tecrübesinde açığa çıabileceğiyle ilgilidir.

\section{Kaynakça}

Akın, G. (2011). Yoz Şiirden Diri Şiire. Şiiri Düzde Kuşatmak: Yazılar, Konuşmalar. İstanbul, Yapı Kredi Yayınları, s. 56-62.

Başaran, A. (2017). İstifham: Sahici Edebiyat Nedir?. Cogito, 89, 235-263.

Bayrav, S. (1998). Filolojinin Oluşumu, İstanbul: Multilingual.

Benjamin, W. (2007). Tekniğin Olanaklarıyla Yeniden Üretilebildiği Çağda Sanat Yapıtı. Pasajlar, Ahmet Cemal (Çev.). İstanbul: Yapı Kredi Yayınları, 50-86.

Blanck, H. (2000). Antikçă̆da Kitap. Zehra Aksu Yılmazer (Çev.). Ankara: Dost Kitabevi Yayınları.

Doğan, M. C. (2011). Mükemmeliyetçiliğin Yarım Bıraktığı Şiirler. Gazi Türkiyat-Türkoloji Araşttrmaları Dergisi. 9, 101-113.

de Man, P. (2002). Return to philology. The Resistance to Theory. Minneapolis and London: University of Minnesota Press, 21-26.

de Saussure, F. (1998). Genel Dilbilim Dersleri. Berke Vardar (Çev.). İstanbul: Multilingual.

Dilthey, W. (1999). Hermeneutik ve Tinbilimleri. Doğan Özlem (Çev.). İstanbul: Paradigma.

Gündoğdu, A. G. (2019). Okumanın Tarihselliği ve Alımlama Estetiği ile Yeni Tarihselcilikte Anlamanın Tarihselliğinin İmkân ve Sinırlılıkları. Milel ve Nihal. 16(2), 351-374.

Heidegger, M. (2008). Varlık ve Zaman, Kaan Ökten (Çev.). İstanbul: Agora.

Hoy, D. C. (2009). The Time of Our Lives: A Critical History of Temporality. Cambridge and London: The MIT Press.

Irvine, M. and Thomson, D. (2005). Grammatica and Literary Theory. The Cambridge History of Literary Criticism. The Middle Ages. Minnis, A. And Johnson, I. (Ed.), New York: Cambridge University Press, 2, 15-41.

Koç, T. (2016). "Varlıkla Buluşan Dil". Akademik Araştırmalar Dergisi, 61. 63-82.

Köprülü, M. F. (1999). Türk Edebiyatı Tarihi’nde Usûl. Edebiyat Araştırmaları. Ankara: Türk Trih Kurumu, 3-47.

Lévi-Strauss, C. (2012). Yapısal Antropoloji. Adnan Kahiloğulları (Çev.). İstanbul: İmge.

Michon, P. New Artistic Rhythm Practices and Conceptions (1857-1897). Rhuthmos. 8 Juillet 2016. http://rhuthmos.eu/spip.php?article1836. Erişim Tarihi: 15 Ağustos 2020.

Sayın, Z. (1996). Sahicilik İlkesi ve Çokkültürcülük. Cogito, 8, 282-288.

Starobinski, J. (2010). Eleştirel İlişki. Gülnihal Gülmez (Çev.), İstanbul: Yapı Kredi.

Tanpınar, A. H. (2004). Tanzimat'ta Tiyatro. Edebiyat dersleri: Gözde Sağnak, Ali F. Karamanloğlu ve Mehmed Çavuşoğlu'nun Ders Notları. Abdullah Uçman (Haz.). İstanbul: Yapı Kredi, 137139.

Tatar, B. (2014). Edebi Hermenötik. Din, İlim ve Sanatta Hermenötik. İstanbul: İSAM Yayınları, 3975 .

Tatar, B. (2004). Hermenötik. İstanbul: İnsan.

Taylor, C. (2011). Modernliğin Sikıntıları. Uğur Canbilen (Çev.). İstanbul: Ayrıntı.

Uygur, N. (1985). Biricik. İnsan Açısından Edebiyat. İstanbul: Remzi Kitabevi, 27-39.

Vernant, J. P. (1996). Eski Yunanda Söylen ve Toplum. Mehmet Emin Özcan (Çev.). Ankara: İmge.

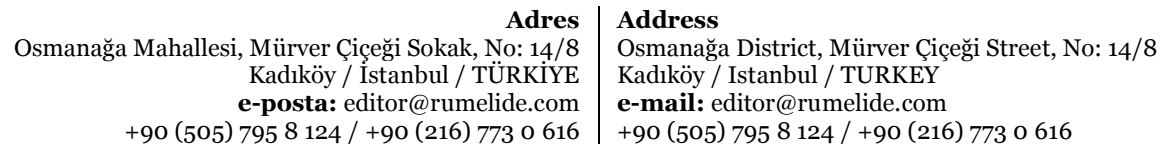


Yahya Kemal (2005). Edebiyata Dair. İstanbul: İstanbul Fetih Cemiyeti.

Yahya Kemal (1974). Kendi Gök Kubbemiz. İstanbul: İstanbul Fetih Cemiyeti, 14-16.

Yavuz, H. (2012). Şairin Zihin Tarihi. İstanbul: Granada.

Ziolkowski, J. (1990). "What is Philology": Introduction. Comparative Literature Studies, 27(1), 1-12. 